\title{
PENGARUH PEMBERIAN BUAH NAGA TERHADAP KADAR HEMOGLOBIN PADA IBU HAMIL TRIMESTER III DI KLINIK BIDAN SRI WAHYUNI KECAMATAN UJUNG PADANG KABUPATEN SIMALUNGUN TAHUN 2020
}

\author{
Desideria Yosepha Ginting, Layari Tarigan, Susi Endriyana \\ Institut Kesehatan Medistra Lubuk Pakam \\ desideriayosepha.ginting@gmail.com
}

\begin{abstract}
ABSTRAK
Anemia atau sering disebut dengan istilah kurang darah merupakan suatu kondisi dengan kadar hemoglobin dalam darah yang berkurang dan mengakibatkan oxygencamying capacity tidak dapat terpenuhi untuk kebutuhan normal tubuh. Masalah yang muncul termasuk terjadinya peningkatan curah jantung dalam upaya menyalurkan oksigen yang maksimal ke seluruh jaringan tubuh, adanya kenaikan frekuensi pernafasan karena tubuh yang usaha menyuplai oksigen dalam darah, sakit kepala yang disebabkan oleh berkurangnya darah yang mengalir ke otak, terasa letih akibat upaya bertambahnya suplai oksigen ke berbagai anggota tubuh termasuk otot jantung dan rangka, permukaan kulit terlihat pucat karena berkurangnya suplai oksigen, timbul enek karena tidak terpenuhinya aliran darah ke saluran pencernaan dan susunan saraf pusat, pengurangan kesehatan rambut dan kulit. Mengatasi keluhan anemia secara nonfarmakologi dapat dilakukan dengan buah naga. Tujuan penelitian ini untuk mengetahui evektifitas buah naga dalam mengatasi keluhan Anemia di klinik Bidan Sri Wahyuni kecamatan Ujung Padang Kabupaten Simalungun Tahun 2020. Penelitian ini menggunakan metode kuantitatif, dengan desain quasi eksperiment dengan rancangan penelitian control time series design. Penelitian ini mengambil populasi ibu hamil dengan gejala anemia di Klinik Sri Wahyuni Kecamatan Ujung Padang Kabupaten Simalungun. Sampel dipilih dengan tehnik purposive sampling sebanyak 14 orang, 7 orang diberikan intervensi dan 7 orang sebagai kontrol. Hasil penelitian ini dianalisis dengan uji wilcoxon sign rank test didapatkan hasil untuk kelompok yang diberikan intervensi pre dan post $p$-value 0,026 $<0,05$. Kesimpulannya adalah ada perbedaan pada kedua kelompok setelah diberikan buah naga dalam mengatasi keluhan Anemia.
\end{abstract}

Kata Kunci: Buah Naga, kadar Hb, Ibu Hamil 


\title{
The Effect Of Giving Dragon Fruit In Hemoglobin Levels In Trimester III Pregnant Women at Midwife Sri Wahyuni Clinic, Ujung Padang District, Simalungun District 2020
}

\begin{abstract}
Anemia, or often referred to as lack of blood, is a condition in which the hemoglobin level in the blood is reduced and results in the oxygen-camying capacity not being met for the body's normal needs. Problems that arise include an increase in cardiac output in an effort to deliver maximum oxygen to all body tissues, an increase in the frequency of breathing due to the body's efforts to supply oxygen in the blood, headaches caused by a lack of blood supply to the brain, feeling tired due to efforts to increase oxygen supply To various parts of the body including the heart and skeletal muscles, the surface of the skin looks pale due to reduced oxygen supply, nausea occurs due to unfulfilled blood flow to the digestive tract and central nervous system, reduced health of hair and skin. Overcoming complaints of anemia non-pharmacological can be done with dragon fruit. The purpose of this study was to determine the effectiveness of dragon fruit in dealing with complaints of anemia in the Sri Wahyuni clinic, Ujung Padang sub-district, Simalungun district in 2020 The research method used is quantitative, with a quasiexperimental design with a control time series design. The population in this study were pregnant women with anemia symptoms at the Sri Wahyuni Clinic, Ujung Padang District, Simalungun Regency. The sample selection using purposive sampling of 14 people, 7 people were given intervention and 7 people as controls. The results of the study using the Wilcoxon sign rank test showed that the results for the group given pre and post intervention p-value $0.026<0.05$. The conclusion is that there are differences in the two groups after being given dragon fruit in overcoming complaints of anemia.
\end{abstract}

Keywords: Dragon fruit, Hb levels, pregnant women 


\section{PENDAHULUAN}

Berdasarkan data yang di peroleh dari World Health Organization (WHO) pada tahun 2015, bahwa lebih dari $30 \%$ atau 2 miliar orang di dunia berstatus anemia. Anemia pada kehamilan adalah keadaan kurang darah yang diakibatkan defisiensi zat besi. Anemia yang disebabkan oleh defisiensi zat besi pada wanita hamil merupakan masalah kesehatan global. Dilaporkan bahwa perempuan mengandung dengan anemia defisiensi zat besi sekitar $35-75 \%$ serta bertambah seiring dengan meningkatnya usia kehamilan. Menurut WHO, di negara berkembang $40 \%$ kematian ibu diakibatkan oleh anemia yang terjadi pada masa kehamilan disebabkan oleh kekurangan zat besi dan perdarahan secara tiba-tiba. Akhir dari persalinan pada wanita hamil yang mengalami anemia kekurangan zat besi adalah kematian janin12-28\%, kematian perinatal $30 \%$ serta angka kematian neonatal 7-10\% (Anggeraini, 2018).
Berdasarkan hasil Survei Data Demografi dan Kesehatan Indonesia (SDKI) pada tahun 2018, angka kematian ibu di Indonesia masih tinggi sejumlah 305 per 1000 kelahiran hidup. Target global SDGs (Sustainable Development Goals) adalah menurunnya angka kematian ibu pada tahun 2030 sampai 70 per 100.000 kelahiran hidup (Departemen Kesehatan, 2015)

Berdasarkan data Riskesdas 2018 jumlah wanita mengandung yang mengalami kurang darah meningkat dari hasil Riskesdas tahun 2013 yaitu sebesar 37,1\%. Dari data tahun 2018, persentase wanita mengandung dengan kurang darah didominas usia 15-24 tahun sejumlah $84,6 \%$, usia $25-34$ tahun sejumlah $33,7 \%$, usia $35-44$ tahun sejumlah $33,6 \%$, dan usia $45-54$ tahun sejumlah $24 \%$.

Kurang darah pada wanita mengandung merupakan salah satu faktor yang menyebabkan angka mortalitas pada ibu masih tinggi. Strategi pelayanan kesehatan masyarakat dasar yang berfokus pada 
ibu dapat dilakukan pada posyandu, karena posyandu merupakan tempat masyarakat berperan serta dalam memberikan dan memdapatkan pelayanan kesehatan dasarnya.

Anemia atau sering disebut dengan istilah kurang darah merupakan suatu kondisi dengan kadar hemoglobin yang menurun dan mengakibatkan oxygencamying capacity tidak dapat terpenuhi untuk kebutuhan normal tubuh. Kebutuhan fisiologis tubuh bervariasi dan setiap orang berbeda tergantung jenis kelamin, ketinggian tempat tinggal dari atas permukaan laut, perokok, dan tahap kehamilan. Diperkirakan $18 \%$ wanita yang tidak di Negara industri mengalami anemia, sedangkan di Negara berkembang jumlah meningkat hingga $56 \%$ dan merupakan faktor yang menyebabkan timbulnya masalah kesehatan pada wanita serta kematian masa hamil dan bersalin (Ertiana, 2018).

Anemia umumnya timbul disebabkan defisiensi zat besi karena pada masa hamil terbentuk kenaikan keperluan zat besi dua kali lipat karena peningkatan volume darah tanpa pertambahan volume plasma, untuk mencukupi kebutuhan ibu (menangkal terbuangnya darah pada saat melahirkan) serta perubahan janin. Kurang darah menggambarkan berkurangnya jumlah masa eritrosit, hingga darah tidak bisa menyempurnakan kerjanya untuk mentransfer oksigen sebanyaknya ke jaringan perifer. Menurut rasinalnya, kurang darah diperlihatkan dengan transisi hemoglobin, hematokrit dan hitung eritrosit. Namun yang umumnya digunakan adalah kadar hemoglobin.

Seorang ibu hamil dikatakan mengalami anemia kalau jumlah hemoglobin (HB) tidak mencapai 10 gr\%. Perempuan tidak hamil memiliki jumlah normal hemoglobin 12-15 gro. Nilai tersebut dipakai juga pada ibu hamil, khususnya perempuan yang harus diawasi sepanjang kehamilan. Oleh kaena itu, harus dilakukan pemeriksaan darah rutin berupa cek $\mathrm{Hb}$ dalam pemantauan antenatal. Semestinya penilikan kadar hemoglobin dilaksanakan per 3 bulan atau 
setidaknya 1 kali pada kunjungan ANC pertama atau trimester 1 dan 1 kali pada 3 bulan terakhir. (Dewi Ertiana, 2018).

Jumlah ibu mengandung yang menyimpan sediaan zat besi dalam tubuh yang sama dengan jumlah keperluan tubuhnya sangatlah minim. Sebesar $25-30 \%$ perempuan tidak menyimpan sediaan zat besi dalam tubuhnya. Sebesar $20 \%$ perempuan memiliki sediaan zat besi tubuh sebesar 250-400 mg dan kurang dari 5\% memiliki cadangan besi tubuh lebih dari 400 mg. Berdasarkan hal ini, wanita dewasa sangat berisiko terkena defisiensi besi dan ADB terlebih pada saat mengalami kehamilan.

Penyebab anemia umumnya adalah: minim gizi (malnutrisi), minim zat besi pada pangan, kendala system pencernaan dalam penyerapan makanan, kehilangan darah yang banyak: riwayat partus yang lalu, mensrtruasi dan lain-lain, kelainan menahun: tbc, organ pernapasan, cacing usus, malaria dan lain-lain. Pada masa kehamilan, nilai darah meningkat (hiperemia/hipervolumia) diakibatkan oleh pencairan darah karena sel-sel darah tidak seimbang kenaikannya dengan plasma darah. Kenyataannya di Thailand ditemukan faktor terpenting penyebab kurang darah pada wanita mengandung adalah kekurangan zat besi $(43,1 \%)$. Demikan juga penelitian di Tanzania menerangkan bahwa anemia pada wanita mengandung berkaitan dengan defisiensi zat besi $(p=0,03)$ vitamin A $(P=0,004)$ dan status gizi (LILA) $\quad(P=0,003)$. Ada hubungan yang kuat antara kurang darah dalam kehamilan dengan kematian janin, abortus, cacat bawaan, berat bayi lahir rendah, dan anak lahir dalam keadaan anemia gizi.

Studi pendahuluan pada tempat penelitian di Klinik Bidan Sri Wahyuni kecamatan ujung padang kabupaten simalungun, pasien yang mengalami keluhan pre menopause yang datang di klinik bidan Sri Wahyuni akan diberikan konseling Kadar $\mathrm{Hb}$ yang rendah pada tiga bulan terakhir usia kehamilannya.

Berdasarkan penelitian Maulina dan Ulya (2015), salah satu pengobatan Non 
farmakologi yang dapat meningkatkan $\mathrm{Hb}$ yaitu pemberian buah naga selama 5 hari sekali sejumlah 250 gram buah naga merah mengandung zat besi yang dapat meningkatkan kadar $\mathrm{Hb}$ pada ibu hamil.

Kandungan yang terdapat di dalam buah naga adalah air $82,5-83,0$, Protein 0,16-0,23, Lemak (g) 0,21-0,61, Serat kasar (g) 0,70-0,90, Abu (g) 0,28, Kalsium (mg) 6,30-8,80, Fosfor (mg) 30,2-36,1 , Besi (mg) 0,55-0,65, Karoten (mg) sangat sedikit, Thiamin (mg), sangat sedikit Riboflavin (mg) sangat sedikit, Niasin (mg) 1,29-1,30, Vitamin C (mg) 8,00-9,00.

Berdasarkan Survei awal di Klinik Bidan Sri Wahyuni Kecamatan Ujung Padang Kabupaten Simalungun di dapatkan sampel sebanyak 16 wanita mengandung pada tiga bulan akhir kehamilannya dengan kurang darah ringan, hasil dari wawancara pada wanita mengandung dengan kurang darah mengatakan sering mengeluh seperti gampang lelah, pucat, kesulitan bernafas, merasakan detak jantung yang tidak normal, tekanan darah normal namun kemungkinan anemia defisiensi, kurang gizi makanan, sering pusing, lidah lecet, kurang selera makan, konsentrasi hilang.

\section{METODE}

Jenis penelitian ini adalah Quasi eksperiment dengan design two group pretest-postest, Controlled Group Design, dimana pada desain penelitian ini peneliti sudah melakukan observasi awal (pretest), sehingga peneliti dapat menguji perubahan yang terjadi setelah adanya intervensi atau tidakan (pemberian buah naga). Desain penelitian ini menggunakan kelompok pembanding. (Riyanto, 2018).

Penelitian ini mengambil populasi yaitu wanita mengandung dengan tiga bulan terakhir kandungannya dengan kurang darah ringan kecamatan ujung padang kabupaten simalungun berjumlah 16 orang. Berdasarkan dari bulan Mei Juni. Sampel dipilih dengan menggunakan tehnik purposive sampling yaitu teknik penentuan sampel berdasarkan pertimbangan peneliti, berdasarkan kriteria inklusi dan ekslusi. 


$$
\text { Jadi besar sampel yang }
$$

didapatkan dari rumus di atas adalah 7 orang sebagai kelompok intervensi dan

7 orang sebagai kelompok control.

Penelitian ini dilakukan di Klinik Bidan Sri Wahyuni. Lokasi penelitian dipilih karena di Klinik Bidan Sri Wahyuni Kecamatan Ujung Padang, Kabupaten Simalungun yaitu belum pernah dilakukan penelitian yang sejenis dan masih banyak ditemukan ibu hamil dengan anemia.

HASIL DAN PEMBAHASAN

\section{Tabel 1}

Ibu Distribusi Frekuensi Hamil Trimester III Yang Mengalami Anemia Ringan Sebelum Dilakukan Pemberian Buah Naga Pada Kelompok Eksperimen Di Klinik Bidan Sri Wahyuni Kecamatan Ujung Padang Kabupaten Simalungun Tahun 2020.

\begin{tabular}{cccc}
\hline & & & Pretest \\
\hline No & Kategori & $F$ & $\%$ \\
& & & \\
\hline $\mathbf{1}$ & Normal & 7 & $100 \%$ \\
& & & \\
\hline & & & \\
\hline & Total & 7 & $100 \%$ \\
\hline
\end{tabular}

\begin{tabular}{llll}
\hline & & \multicolumn{2}{c}{ Pretest } \\
\hline $\mathbf{N}$ & Kategori & $\mathrm{F}$ & \\
$\mathbf{0}$ & & & \\
\hline $\mathbf{1}$ & Ringan & 7 & $100 \%$ \\
& Sekali & & \\
& & & \\
\hline & Total & 7 & $100 \%$ \\
\hline
\end{tabular}

Berdasarkan table diatas $\mathrm{F}$ (Frekuensi) dan \% (Persen), terlihat dari tabel sebelum di berikan buah naga pada anemia ringan sekali sebanyak 7 orang (100\%),

\section{Tabel 2}

\section{Ibu Distribusi Frekuensi Hamil}

Trimester III Yang Mengalami

Anemia Ringan Sesudah Dilakukan

Pemberian Buah Naga Pada

Kelompok Eksperimen Di Klinik

Bidan Sri Wahyuni Kecamatan

\begin{tabular}{ccc} 
Ujung & Padang & Kabupaten \\
& & Pretest \\
\hline
\end{tabular}

\begin{tabular}{cccc}
\hline 1 & Ringan & 4 & $57,14 \%$ \\
& Sekali & & \\
2 & Ringan & 3 & $42,85 \%$ \\
& Total & 7 & $100 \%$
\end{tabular}

Simalungun Tahun 2020. 
Berdasarkan tabel diatas $\mathrm{F}$

(Frekuensi) dan \% (Persen), terlihat dari tabel sesudah diberikan buah naga kadar $\mathrm{Hb}$ normal sebanyak 7 orang $(100 \%)$.

Tabel 3 Trimester III Yang Mengalami Anemia Ringan yang tidak mengkonsumsi tablet Fe dan tidak diberikan buah naga Kelompok Kontrol sebelum Di Klinik Bidan Sri Wahyuni Kecamatan Ujung Padang Kabupaten Simalungun Tahun 2020.

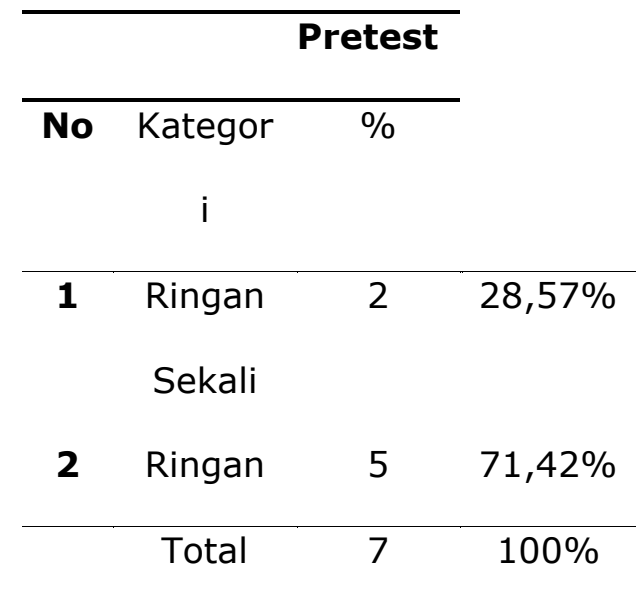

Berdasarkan diatas $\mathrm{F}$ (Frekuensi) dan \% (Persen), terlihat dari tabel kelompok kontrol yang sebelum Ringan sekali yaitu 2 orang $(28,57 \%)$, dan ringan $5(71,42 \%)$.
Tabel 4

Distribusi Frekuensi Ibu Hamil Trimester III Yang Mengalami Anemia Ringan yang tidak mengkonsumsi tablet Fe dan tidak diberikan buah naga Kelompok Kontrol sesudah Di Klinik Bidan Sri Wahyuni Kecamatan Ujung Padang Kabupaten Simalungun Tahun 2020.

$$
\text { Berdasarkan diatas F (Frekuensi) }
$$
dan $\%$ (Persen), terlihat dari tabel kelompok kontrol yang sesudah Ringan sekali yaitu 4 orang $(57,14 \%)$, dan ringan $3(42,85 \%)$.

Tabel 4.7.

Pengaruh Pemberian Buah Naga Terhadap Kadar Hemoglobin Pada Ibu

Hamil Trimester III Di Klinik Bidan SriWahyuni Kecamatan Ujung Padang Kabupaten Simalungun Tahun 2020 
Jurnal Kesehatan Masyarakat \& Gizi, e-ISSN: 2655-0849

Vol. 3 No.2 Edisi November 2020 - April 2021

https://ejournal.medistra.ac.id/index.php/JKG

Received: 15 April 2021 :: Accepted: 29 April 2021 :: Published: 30 April 2021

Berdasarkan tabel 4.7 dapat di lihat, bahwa rata rata $\mathrm{Hb}$ sebelum diberikan buah naga pada hamil trimester III yang mengalami anemia sebesar 10,0000, sedangkan rata rata $\mathrm{Hb}$ sesudah diberikan buah naga pada ibu hamil Trimester III sebesar 10,9429. Hal ini

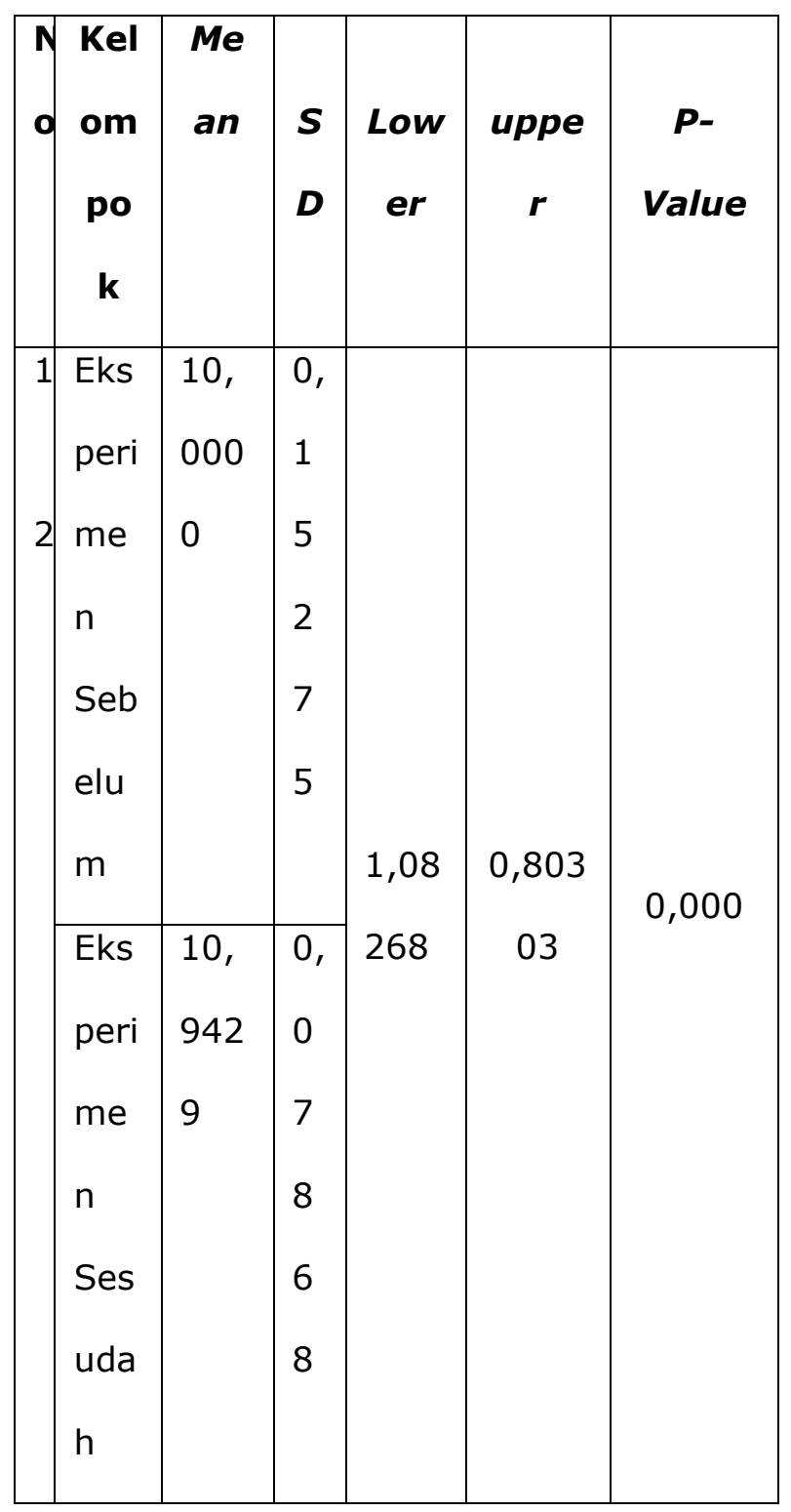

dapat disimpulkan bahwa susudah diberikan buah naga responden mengalami efek peningkatan $\mathrm{Hb}$ keluhan sebesar 0,9429 poin. Hal uji statistic ini menggunakan uji Paired Sample T-Test dan Unpaired Sample T Test di dapatkan $p$-value 0,000<0,05. Maka $\mathrm{H}_{0}$ di tolak artinya ada perbedaan sebelum dan sesudah pemberian buah naga terhadap kadar $\mathrm{Hb}$ pada ibu hamil trimester III di Klinik Bidan Sri Wahyuni Kecamatan Ujung Padang Kabupaten Simalungun Tahun 2020.

Pengaruh Pemberian Susu Kedelai Terhadap Keluhan Sebelum dan Sesudah Kelompok Kontrol Di Klinik Bidan Sri Wahyuni Kecamatan Ujung Padang Kabupaten

\section{Simalungun Tahun 2020}




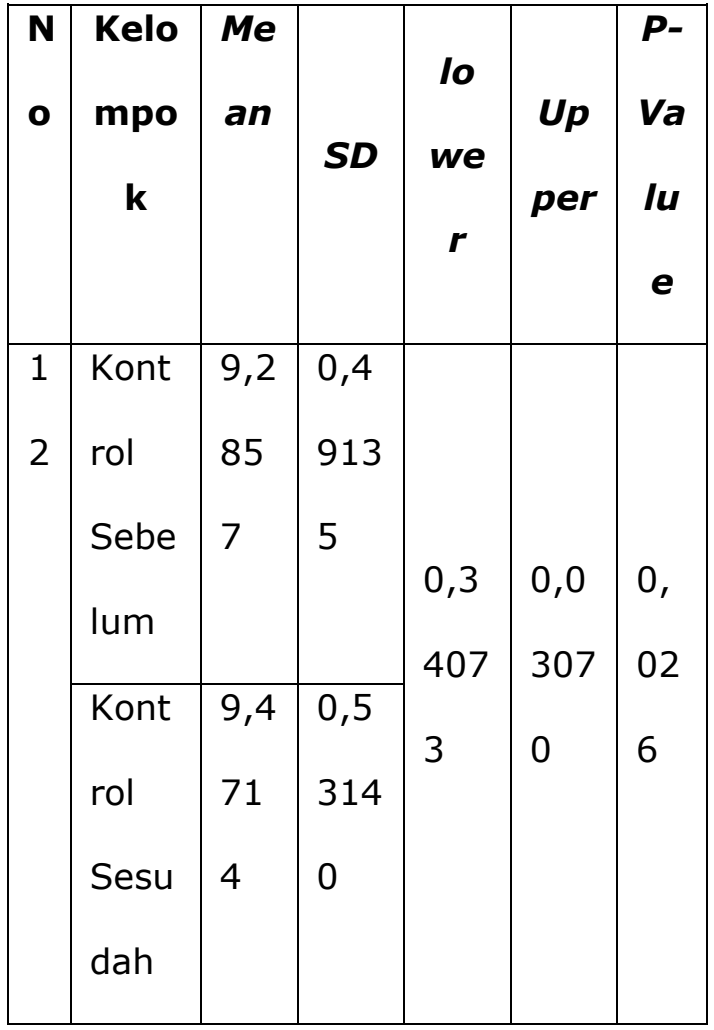

Berdasarkan tabel bahwa rata-rata kontrol sebelum sebesar 9,2857, dan kelompok kontrol sesudah sebesar 9,4714. Hal uji statistic ini menggunakan uji statistic ini menggunakan uji Paired Sample T-Test dan Unpaired Sample T Test di dapatkan $p$-value $0,026<0,05$. Maka $\mathrm{H}_{0}$ di tolak artinya ada perbedaan kelompok kontrol dengan kelompok sesudah dilakukan terhadap keluhan pada ibu hamil trimester III yang mengalami anemia ringan di Klinik Bidan Sri Wahyuni Kecamatan Ujung Padang Kabupaten Simalungun Tahun 2020

\section{PEMBAHASAN}

\section{A. Intensitas keluhan pada ibu} hamil yang mengalami anemia ringan sebelum dilakukan

\section{pemberian buah naga}

Anemia atau sering disebut dengan istilah kurang darah merupakan suatu kondisi dengan jumlah sel darah merah berkurang dan mengakibatkan oxygen-camying capacity tidak mencukupi untuk memenuhi kebutuhan fisiologis tubuh. Masalah yang muncul termasuk terjadinya peningkatan kecepatan denyut jantung karena tubuh berusaha memberi oksigen lebih banyak ke jaringan, adanya peningkatan kecepatan pernafasan karena tubuh berusaha menyediakan lebih banyak oksigen pada darah, pusing akibat kurangnya darah ke otak, terasa lelah karena meningkatnya oksigenasi berbagai organ termasuk otot jantung dan rangka, kulit pucat karena berkurangnya oksigenasi, mual akibat penurunan aliran darah saluran cerna dan susunan saraf pusat, penurunan kualitas rambut dan kulit. 
Berdasarkan penelitian yang

telah dilakukan $28,57 \%$ responden mengalami keluhan anemia ringan sekali bahwa separuh dari responden mengalami keluhan anemia ringan $71,42 \%$. Keluhan pada ibu hamil Trimester III yang mengalami anemia ringan dapat mengganggu aktivitas pada ibu karena mengalami gejala yang sering timbul seperti peningkatan kecepatan denyut jantung karena tubuh berusaha memberi oksigen lebih banyak ke jaringan, adanya peningkatan kecepatan pernafasan karena tubuh berusaha menyediakan lebih banyak oksigen pada darah, pusing akibat kurangnya darah ke otak, terasa lelah karena meningkatnya oksigenasi berbagai organ termasuk otot jantung dan rangka, kulit pucat karena berkurangnya oksigenasi, mual akibat penurunan aliran darah saluran cerna dan susunan saraf pusat, penurunan kualitas rambut dan kulit

\section{Perbedaan Kadar Hemoglobin}

Sebelum dan Sesudah Pemberian

Buah Naga Pada Ibu Hamil Di Klinik

Bidan Sri Wahyuni Kecamatan

\section{Ujung Padang Kabupaten}

\section{Simalungun Tahun 2020}

Berdasarkan hasil analisa Uji ini menggunakan uji Paired Sample T-Test dan Unpaired Sample T Test di dapatkan $p$-value $0,000<0,05$. Maka $\mathrm{H}_{0}$ di tolak artinya ada perbedaan sebelum dan sesudah pemberian buah naga terhadap kadar $\mathrm{Hb}$ pada ibu hamil trimester III di Klinik Bidan Sri Wahyuni Kecamatan Ujung Padang Kabupaten Simalungun Tahu.

Hasil Penelitian ini sesuai dengan Eduharma,(2019),bahwa setelah dilakukan uji statistik didapat hasil pvalue $0,000<0,05$. Maka dapat disimpulkan bahwa $\mathrm{H}_{0}$ ditolak dan $\mathrm{Ha}$ diterima yang artinya adanya pengaruh pemberian buah naga terhadap kadar hemoglobin pada ibu hamil .

Buah Naga mengandung vitamin B12 (ribofavin) yang terkandung dalam buah naga adalah untuk menjaga sistem syarat tetap sehat dan melancarkan proses replikasi DNA. Selain itu, vitamin B12 juga membantu mengatur pembentukan sel darah merah (hemoglobin) dalam tubuh, selama 5 
hari mengonsumsi buah naga sebanyak

250 gram dapat meningkatkan

hemoglobin pada ibu hamil hal ini dikarenakan buah naga mengandung $1,6 \mathrm{mg}$ zat besi.

Cara lain untuk menurunkan angka keadian anemia pada ibu hamil tidak hanya dengan diberikan tablet tambah darah, tetapi harus ditunjang dan dbantu dengan memberikan asupa nutrisi ang kaa akan zat beri. Vitamin C dapat meningkatkan absorbsi zat besi nonheme sampai $4 x$ lipat. Vitamin $C$ dengan zat besi mempunyai senawa ascorbat besi kompleks yang larut dan mudah diabsorbsi, karena itu sayursayuran segar dan buah buahan ang mengandung banak itamin $\mathrm{C}$ dikonsumsi untuk mencegah anemia.

\section{KESIMPULAN}

1.Ada pengaruh terhadap kadar hemoglobin pada ibu hamil sebelum dan sesudah di berikan buah naga di Klinik Bidan Sri Wahyuni Kecamatan Ujung Padang Kabupaten Simalungun Tahun 2020 dengan $p$ value $0,000<0,05$. Maka $\mathrm{H}_{0}$ di tolak artinya ada pengaruh sebelum dan sesudah pemberian buah naga terhadap kadar hemoglobin pada ibu hamil. Sehingga dapat disimpulkan buah naga efektif dalam meningkatkan kadar hemoglobin pada ibu hamil.

\section{SARAN}

1. Bagi Ibu Hamil

Bagi responden agar dapat memanfaatkan buah naga untuk meningkatkan kadar hemoglobin pada ibu hamil, ini juga sebagai salah satu cara nonfarmakologi yang aman dan mudah untuk di dapatkan di rumah dan juga dapat mendukung serta memfasilitasi teman dan anggota keluarga lainnya dalam mengkonsumsi buah naga untuk meningkatkan kadar Hemoglobin

\section{Bagi Peneliti}

Bagi peneliti dapat menambah ilmu pengetahuan dan memperdalam pengalaman peneliti tentang riset kebidanan serta pengembangan wawasan tentang pengobatan nonarmakologi dengan mengkonsumsi buah naga. 
3 Bagi Peneliti Selanjutnya

Bagi peneliti selanjutnya diharapkan dapat membuka wawasan yang lebih luas. Diharapkan untuk pelaksanaan penelitian selanjutnya untuk menambah jumlah responden, dan dapat menemukan obat herbal atau nonfarmakologi lainnya yang dapat meningkatkan kadar hemoglobin pada ibu hamil.

4. Bagi Masyarakat di Kelurahan Pagar Bosi

Diharapkan hasil penelitian ini dapat memberikan salah satu alternatif pengobatan dalam meningkatkan kadar hemoglobin pada ibu hamil yang mengalami anemia ringan.

\section{DAFTAR PUSTAKA}

Puspita dkk, (2019). Pengaruh Pemberian Buah Naga Terhadap Peningkatan Kadar Hemoglobin Pada Ibu Hamil Di Puskesmas Sindang Jaya Kabupaten Tangerang, Jurnal Edudharma. 2019,
Hendarto, D. (2018). Khasiat Ampuh Buah Naga Dan Delima . Jakarta : Salemba Medika

Hilda dkk. 2018. " Buah Naga Meningkatkan Kadar Hemoglobin Pada Remaja Putri ".Universitas Muslim Indonesia.

Wahyuni Ningrum. 2009 "Pemberian Tablet Fe Pada Ibu Hamil Untuk Mencegah Anemia"

http://ningrumwahyuni.wordpres. com/2009/(22 Maret 2019)

Fathonah, S. (2016). Gizi dan Kesehatan Untuk Ibu Hamil. Jakarta : Rineka Cipta

Hilda dkk. 2018. " Buah Naga Meningkatkan Kadar Hemoglobin Pada Remaja Putri ".Universitas Muslim Indonesia.

Manuaba, L.A.C. 2008. Buku ajar patologi obstetric untuk mahasiswa kebidanan. Jakarta : EGC

Kres, D. (2018). Bertanam Buah Naga. Jakarta :Gramedia Pustaka Sinarna, H. (2017). Budi Daya Buah Naga Super Red Secara Organik. Jakarta : Gramedia Pustaka 
Jurnal Kesehatan Masyarakat \& Gizi, e-ISSN: 2655-0849

Vol. 3 No.2 Edisi November 2020 - April 2021

https://ejournal.medistra.ac.id/index.php/JKG

Received: 15 April 2021 :: Accepted: 29 April 2021 :: Published: 30 April 2021

Munadira dkk. (2019). "Pengaruh

4 Pangkep".Universitas Muslim

Pemberian

Jus Buah Naga

Indonesia.

Terhadap

Peningkatan

Hemoglobin Pada Remaja Putri

Yang Mengalami Anemia Di SMAN 